\title{
KONSUMSI MIKRONUTRIEN DAN EKSPRESI GEN eNOS3 ALEL INTRO 4a4b PADA PENDERITA HIPERTENSI ETNIK MINANGKABAU
}

\author{
Delmi Sulastri \\ Bagian Ilmu Gizi Fakultas Kedokteran Universitas Andalas \\ E-mail : delmisulastri@yahoo.com
}

\begin{abstract}
Abstrak
Gen eNOS3 varian intron 4a4b merupakan salah satu gen yang berhubungan dengan kejadian hipertensi esensial. Kemampuan Gen eNOS3 varian ini untuk mensintesis enzim nitric oxide synthase (NOS) berkurang sehingga sintesis Nitric oxide (NO) menurun. Senyawa NO adalah suatu senyawa vasoaktif yang menyebabkan vasodilatasi pembuluh darah.

Penelitian pada subjek hipertensi dan normotensi berusia 30-65 tahun bertujuan untuk melihat pengaruh mikronutrien terhadap ekspresi gen eNOS3 alel intron 4a4b. 130 subjek, diwawancara pola makannya lalu dilakukan analisis asupan mikronutrien, gen eNOS3, serta kadar NO plasma. Data yang diperoleh dianalisis menggunakan uji $\mathrm{T}$ dan chi-square.

Kadar NO plasma penderita hipertensi adalah $26.91 \pm 15.40 \mu \mathrm{M} / \mathrm{L}$ dan normotensi $25.79 \pm 15.04 \mu \mathrm{M} / \mathrm{L}$. $55.5 \%$ subjek hipertensi memiliki gen eNOS3 varian intron $4 \mathrm{~b}$ dan $69 \%$ subjek normotensi mempunyai varian intron 4a4b. Kadar NO plasma rendah, $(66.7 \%)$ ditemukan pada subjek hipertensi dengan varian intron $4 \mathrm{~b}$. Tidak terdapat hubungan bermakna asupan mikronutrien dengan kadar NO plasma pada subjek hipertensi.

Hasil ini tidak mendukung pengaruh konsumsi mikronutrien terhadap kadar NO plasma pada penderita hipertensi dengan gen eNOS3 varian intron 4a4b.

Kata Kunci : hipertensi esensial, gen eNOS3, kadar NO plasma
\end{abstract}

\section{Abstract}

eNOS 3 gene intron $4 \mathrm{a} 4 \mathrm{~b}$ allel is one of the important genes which is related to hypertesion essensial. This gene expresses the nitric oxide synthase (NOS) enzyme which regulates the synthesis of Nitric oxide (NO) in human body. NO causes vasodilatation, which decreases peripheral resistant and blood pressure.

A research has been done based on cross sectional study on hypertension patients and those with normal blood pressure in the range of 30-65 years old. The main of this research is to evaluate the influence of micronutrient consumption on eNOS3 gene intron $4 \mathrm{a} 4 \mathrm{~b}$ allel expression in hypertension subjects in Minangkabau ethnicity. 130 subjects interviewed about micronutrient consumption and the 
assessment of eNOS3 gene and NO plasma level were done. The Data was analysed with t-test and chi-square.

The results of this study showed that the hypertensive's plasma NO concentration was $26.91 \pm 15.40 \mu \mathrm{M} / \mathrm{L}$ and normotensive's was $25.79 \pm 15.04 \mu \mathrm{M} / \mathrm{L} .55 .5 \%$ of the hypertensive group has eNOS3 gene intron $4 \mathrm{~b}$ alleles and $69 \%$ of the normotensive group has eNOS3 gene intron $4 \mathrm{a} 4 \mathrm{~b}$ alleles . Low NO plasma level can be found at $66.7 \%$ subject hypertension with eNOS3 gene allel intron 4b. There was no significant relationship between consumption of micronutrient with NO plasma level in hypertension patients.

This result did not support that consumption micronutrient can influenced NO plasma level in hypertension subject with eNOS3 gene allel 4a4b.

Key word : essensial hypertension, eNOS3 gene, NO plasma level. 


\section{Pendahuluan}

Hipertensi merupakan masalah kesehatan masyarakat yang penting dan telah lama dikenal sebagai penyakit yang dapat memperpendek umur. Pada stadium dini penyakit ini seringkali tanpa keluhan dan gejala, serta tidak disadari oleh penderita tetapi lambat laun dapat menyebabkan komplikasi yang berat pada organ tubuh. ${ }^{(1)}$

Hipertensi merupakan suatu penyakit yang ditandai dengan peningkatan tekanan darah di atas nilai normal, yaitu nilai sistolik $\geq 140 \mathrm{mmHg}$ dan atau diastolik $\geq 90 \mathrm{mmHg}$ (Kriteria Join National Commiteel JNC VII, 2003). Penyakit ini dapat memberi gejala berlanjut untuk suatu target organ, seperti otak, pembuluh darah dan otot jantung. Saat ini hipertensi sudah menjadi masalah utama kesehatan mesyarakat yang ada di Indonesia maupun di beberapa negara yang ada di dunia. ${ }^{(2)}$ Hampir separuh penduduk dewasa Eropa dan seperempat penduduk dunia menderita hipertensi. Data dari The National Health and Nutrition Examination Survey (NHNES) menunjukkan dari tahun 1999 - 2000 insiden hipertensi pada orang dewasa adalah $29 \%-32 \%$, ini berarti bahwa terdapat $58-65$ juta orang menderita hipertensi di Amerika dan terjadi peningkatan 15 juta dari data tahun $1988-1991$ ( $^{(3)}$

Prevalensi hipertensi di seluruh dunia sekitar $15 \%$ - 20\% sedangkan di Asia sudah mencapai $8 \%$ - 18\%. Pada tahun 2025 diperkirakan terjadi kenaikan kasus hipertensi sekitar $80 \%$, yaitu dari 639 juta kasus di tahun 2000, menjadi 1,15 milyar kasus pada tahun 2025. Peningkatan tersebut terutama terjadi di negara sedang berkembang. Prediksi ini berdasarkan angka penderita hipertensi dan pertambahan penduduk saat ini. ${ }^{(3.4)}$
Data tentang prevalensi hipertensi di Indonesia telah banyak dilaporkan tetapi karena Indonesia merupakan negara kepulauan dengan banyak suku bangsa, sehingga sulit untuk mendapatkan prevalensi hipertensi secara pasti. Beberapa penelitian melaporkan prevalensi hipertensi di Indonesia berkisar antara $17 \%$ sampai $21 \%$, sedangkan menurut laporan Depkes RI (2007) ${ }^{(5)}$ prevalensi hipertensi di Indonesia adalah 29,8\%. Angka-angka ekstrim rendah dapat ditemukan di Ungaran Jawa Tengah yaitu 1,8\%, Lembah Baliem Pegunungan Jaya Wijaya Irian Jaya $0,6 \%$ dan ekstrim tinggi di Talang Sumatera Barat $17,8 \%$. Wanita mempunyai prevalensi lebih tinggi dari pada pria. $^{(2.6)}$ Prevalensi hipertensi di Sumatera Barat juga cenderung meningkat. Pada tahun 1977 prevalensi hipertensi hanya $7,3 \%{ }^{(6)}$ kemudian pada tahun 2007, hasil riset kesehatan dasar yang dilakukan Departemen Kesehatan RI melaporkan bahwa prevalensi hipertensi di Sumatera Barat sudah mencapai $31,2 \%$.

Sembilan puluh lima persen penderita hipertensi tidak diketahui penyebabnya dan dikenal sebagai hipertensi primer atau esensial. Beberapa mekanisme yang mungkin berkontribusi untuk terjadinya hipertensi ini telah diidentifikasi, namun belum satupun teori yang tegas menyatakan patogenesis hipertensi tersebut. Interaksi antara faktor genetik dan lingkungan di duga mempunyai kontribusi yang besar terhadap hipertensi. $^{(7)}$

Gen eNOS3 adalah gen yang berhubungan dengan patogenesis hipertensi. Varian dari gen eNOS3 belum semuanya teridentifikasi, tetapi intron $4 \mathrm{a} 4 \mathrm{~b}$ merupakan salah satu varian gen eNOS3 yang berhubungan 
dengan kejadian hipertensi. Beberapa vasodilatasi terhadap pembuluh darah penelitian melaporkan bahwa poli- menurun sehingga terjadi peningkatan morfisme gen eNOS3 memberikan tahanan perifer. Penurunan kemampuan faktor risiko yang berbeda antara etnik vasodilatasi pembuluh darah juga Asia dengan nonAsia terhadap terjadi pada kapiler di ginjal, keadaan hipertensi. Etnik Asia dan nonAsia ini akan mengakibatkan glomerolus dengan gen eNOS3 varian intron $4 \mathrm{a} 4 \mathrm{~b}$ filtration rate (GFR) menurun, sistem mempunyai faktor risiko yang sama renin angiotensin teraktivasi dan menderita hipertensi, ${ }^{(8.9)}$ sedangkan akhirnya terjadi peningkatan tekanan penelitian yang dilakukan terhadap darah. Senyawa NO yang berasal dari masyarakat Korea, didapatkan hasil endotelium dianggap sebagai suatu bahwa varian intron 4a4b berhubungan senyawa yang bersifat ateroprotektif bermakna dengan kejadian hipertensi. sehingga gangguan pada sintesis NO (10) Individu yang memiliki varian ini dihubungkan dengan meningkatnya akan mengalami gangguan ekspresi risiko penyakit kardiovaskuler protein gen eNOS3 sehingga kadar NO (PKV), ${ }^{(8.11-13)}$ disamping itu senyawa plasma menurun. ${ }^{(8)}$

Gen eNOS3 adalah gen yang NO di dalam darah akan berikatan mengekspresikan senyawa Endothelial

Nitric Oxide Synthase (eNOS). Senyawa ini merupakan suatu enzim yang tersebar pada otot polos. Enzim tersebut mengkatalisis reaksi asam amino L-arginin menjadi sitrulin dan nitric oxide. Senyawa NO merupakan suatu endothelium-derived relaxing factor (EDRF) yang dalam kondisi fisiologis dilepaskan dari sel endotel sebagai respon terhadap asetilkolin dan peningkatan kalsium intraseluler. Senyawa NO dapat menyebabkan relaksasi vaskular dan berperan sebagai regulator tonus otot polos melalui aktivasi soluble guanylate cyclase dan memperbaiki perfusi jaringan dengan menghambat adhesi dan agregasi trombosit serta menghambat adhesi leukosit pada permukaan endotel. Di samping itu NO secara tidak langsung juga dapat menyebabkan vasorelaksasi pembuluh darah dengan cara menghambat pelepasan renin dan norepinefrin.

Pada penderita hipertensi esensial, sintesis NO di bawah nilai basal. ${ }^{(9)}$ Hal ini menyebabkan efek dengan homosistein membentuk senyawa S-NO-Hcy, homosistein darah akan turun, akibatnya risiko hiperhomosistein terhadap hipertensi akan berkurang. ${ }^{(10)}$

Pada penderita hipertensi, disamping kemampuan gen eNOS3 mensintesis NO menurun, pola makan yang tidak seimbang akan memperburuk produksi NO, tetapi pola makan yang mengandung tinggi antioksidan dapat meningkatkan sintesis NO plasma. ${ }^{(14-16)}$

Etnik Minangkabau adalah masyarakat yang sebagian besar bertempat tinggal di Sumatera Barat. Daerah ini terdiri dari daerah pantai dan pegunungan dengan pola makan yang khas. Beberapa penelitian yang pernah dilakukan, melaporkan bahwa etnik Minangkabau mempunyai pola makan tinggi lemak jenuh dan rendah sayursayuran serta buah-buahan sebagai sumber antioksidan dan serat. Berdasarkan uraian di atas, maka kami ingin melihat hubungan asupan antioksidan dengan ekspresi gen eNOS3 varian intron $4 \mathrm{a} 4 \mathrm{~b}$ pada penderita hipertensi etnik Minangkabau. 
Metode

Penelitian ini merupakan studi komperatif dengan desain cross sectional study, dilakukan di 4 kecamatan di Kota Padang Provinsi Sumatera Barat pada tahun 2009.

Populasi adalah semua penderita hipertensi dan normotensi yang berusia antara $30-65$ tahun, etnik Minangkabau (berdomisili di Sumatera Barat, kedua orang tua serta kakek nenek berasal dari Sumatera Barat) dan diperoleh melalui penjaringan terhadap 800 orang calon subjek. Subjek yang memenuhi kriteria inklusi dan eksklusi (hipertensi sekunder, DM, dislipidemia, merokok, atlit, infeksi, post operasi saluran cerna, menjalani diet) diperoleh sebanyak 130 orang yang terdiri dari 65 subjek hipertensi esensial dan 65 subjek normotensi. Pengambilan subjek studi dengan cara sistematic random sampling.

Polimorfisme gen eNOS3 alel intron $4 \mathrm{a} 4 \mathrm{~b}$ diperoleh melalui ekstraksi DNA dari darah subjek, kemudian dilanjutkan dengan amplifikasi polymerase chain reaction (PCR) serta dikonfirmasi dengan hasil sekuensing (metoda Sanger), sedangkan kadar NO plasma diperoleh dari hasil pemeriksaan 3 cc serum dengan menggunakan teknik ELISA. Asupan antioksidan dinilai dengan semiquantitatif Food Frequency Questioner (FFQ) dan diolah menggunakan metode nutrisurvey. Setelah data dikumpulkan kemudian diolah dengan komputer dan dianalisis menggunakan uji $\mathrm{T}$ untuk melihat perbedaan rerata kadar NO plasma dan asupan antioksidan serta uji Chi Square untuk melihat pengaruh asupan mikronutrien terhadap ekspresi gen eNOS3 intron 4a4b.

\section{Hasil Penelitian}

Gambaran Umum Daerah Penelitian

Kota Padang adalah Ibukota Propinsi Sumatera Barat dengan luas wilayah 694,96 km2 memiliki penduduk sebanyak 784.740 jiwa dengan kepadatan penduduk sekitar $1.129 \mathrm{jiwa} / \mathrm{km} 2$. Kota ini terdiri dari 11 Kecamatan dan 104 Kelurahan (Padang Dalam Angka, BPS Provinsi Sumatera Barat, 2004).

Penelitian dilakukan pada 4 kecamatan yaitu Kecamatan Padang Utara, dan Kecamatan Padang Barat, Kecamatan Pauh dan Kecamatan Lubuk Kilangan. Pada setiap kecamatan dipilih 2 kelurahan dan dilakukan penjaringan sampel terhadap 800 orang populasi yang dipilih secara sistematic random sampling.

Dari hasil penjaringan diperoleh 130 sampel dengan karakteristik sebagai berikut, subjek penelitian dengan jenis kelamin wanita lebih banyak dibandingkan laki-laki yaitu 51 orang $(78.5 \%)$ dan sebagian besar sampel berusia $\geq 40$ tahun yaitu 62 org (95.4\%) pada kelompok kasus dan 57 orang $(87.7 \%)$ kelompok kontrol. Subjek penelitian dengan tingkat pendidikan rendah lebih banyak pada kedua kelompok masing-masing 64.6\% dan $56.9 \%$. Lebih dari separoh subjek penelitian tidak bekerja. (Tabel 1) 
ALEL INTRO 4a4b PADA PENDERITA HIPERTENSI ETNIK

MINANGKABAU

Tabel 1. Karakteristik Subjek Penelitian

\begin{tabular}{|c|c|c|c|c|}
\hline \multirow{2}{*}{ Karakteristik Subjek Penelitian } & \multicolumn{2}{|c|}{ Hipertensi } & \multicolumn{2}{|c|}{ Normotensi } \\
\hline & f & $\%$ & $\mathbf{f}$ & $\%$ \\
\hline \multicolumn{5}{|l|}{ Jenis Kelamin } \\
\hline Pria & 14 & 21.5 & 14 & 21.5 \\
\hline Wanita & 51 & 78.5 & 51 & 78.5 \\
\hline \multicolumn{5}{|l|}{ Umur } \\
\hline$<40$ tahun & 3 & 4.6 & 8 & 12.3 \\
\hline$\geq 40$ tahun & 62 & 95.4 & 57 & 87.7 \\
\hline \multicolumn{5}{|l|}{ Tingkat pendidikan } \\
\hline Rendah & 42 & 64.6 & 37 & 56.9 \\
\hline Tinggi & 23 & 35.4 & 28 & 43.1 \\
\hline \multicolumn{5}{|l|}{ Status Pekerjaan } \\
\hline Tidak Bekerja & 36 & 55.4 & 34 & 52.3 \\
\hline Swasta & 20 & 30.8 & 24 & 36.9 \\
\hline PNS/ABRI & 9 & 13.8 & 7 & 10.8 \\
\hline
\end{tabular}

Rerata tekanan darah sistolik pada kelompok kasus adalah $152 \pm 17,64$ mmHg dan diastolik 90,27 \pm 6,25 mmHg, sedangkan pada kelompok kontrol rerata tekanan darah sistolik $114,84 \pm 9,26 \mathrm{mmHg}$ dan diastolik $74,54 \pm 6,28 \mathrm{mmHg}$.
Asupan mikronutrien yang terdiri dari asupan vitamin A, karotenoid, vitamin $\mathrm{C}$, vitamin $\mathrm{E}$ dan flavonoid diukur dengan menggunakan semikuantitatif FFQ. Pada tabel 2 dapat dilihat perbedaan rerata asupan mikronutrien pada subjek penelitian.

Tabel 2 Perbedaan Rerata Asupan Mikronutrien pada Subjek Penelitian

\begin{tabular}{|c|c|c|c|c|c|c|}
\hline Zat Gizi & Kelompok & Mean & SD & Min & Mak & $p$ value \\
\hline \multirow{2}{*}{$\begin{array}{l}\text { Vit C } \\
(\mathrm{mg} / \mathrm{hr})\end{array}$} & Kasus & 159.06 & 85.45 & 13.05 & 409.74 & \multirow[t]{2}{*}{0.94} \\
\hline & Kontrol & 140.97 & 85.25 & 31.86 & 409.74 & \\
\hline \multirow{2}{*}{$\begin{array}{l}\text { Vit E } \\
(\mathrm{mg} / \mathrm{hr})\end{array}$} & Kasus & 14.65 & 8.13 & 5.23 & 53.8 & \multirow[t]{2}{*}{0.15} \\
\hline & Kontrol & 15.38 & 11.11 & 2.10 & 77.30 & \\
\hline \multirow{2}{*}{$\begin{array}{l}\text { Retinol } \\
\text { (IU) }\end{array}$} & Kasus & 437.98 & 242.83 & 0.00 & 1539.22 & \multirow[t]{2}{*}{0.25} \\
\hline & Kontrol & 536.80 & 914.97 & 25.40 & 7582.01 & \\
\hline \multirow{2}{*}{$\begin{array}{l}\text { Karotenoid } \\
(\mathrm{mg})\end{array}$} & Kasus & 6123.25 & 4285.72 & 371.90 & 1769.99 & \multirow[t]{2}{*}{$0.001 *$} \\
\hline & Kontrol & 3893.63 & 2697.16 & 146.00 & 9653.79 & \\
\hline \multirow{2}{*}{$\begin{array}{l}\text { Flavonoid } \\
(\mathrm{mg})\end{array}$} & Kasus & 117.14 & 60.23 & 31.20 & 328.40 & \multirow[t]{2}{*}{0.18} \\
\hline & Kontrol & 101.51 & 46.08 & 8.10 & 203.30 & \\
\hline
\end{tabular}

Hasil uji statistik menunjukkan bahwa tidak terdapat perbedaan bermakna rerata asupan retinol, vitamin $\mathrm{C}$, vitamin $\mathrm{E}$ dan flavonoid antara kedua kelompok tetapi terdapat berbedaan bermakna asupan karotenoid antara kelompok kasus dengan kelompok kontrol (Tabel 2). 
Tabel 3 Perbedaan Rerata Kadar NO Plasma Pada Subjek Penelitian

\begin{tabular}{lllcccc}
\hline \multicolumn{1}{c}{ Variabel } & Kelompok & Mean & SD & Min & Mak & p value \\
\hline Kadar NO & Kasus & 26.91 & 15.40 & 6.00 & 66.00 & 0.68 \\
$\mu \mathrm{M} / \mathrm{L}$ & Kontrol & 25.79 & 15.04 & 9.00 & 67.50 & \\
\hline
\end{tabular}

Dari Tabel 3 dapat disimpulkan bahwa tidak terdapat perbedaan bermakna rerata kadar NO plasma antara kelompok kasus dengan kelompok kontrol. Rerata kadar NO plasma pada kelompok kasus lebih tinggi daripada kelompok kontrol, tetapi masih dalam batas normal.
Hubungan Pola Makan dengan Polimorfisme Gen eNOS3 Intron 4a4b

Polimorfisme intron $4 a 4 b$ didapatkan dengan cara DNA langsung diamplifikasi dengan menggunakan primer intron 4a4b. Hasil Amplifikasi selanjutnya dielektroforesis menggunakan agarose $2.5 \%$ dan diperoleh hasil seperti gambar dibawah ini.

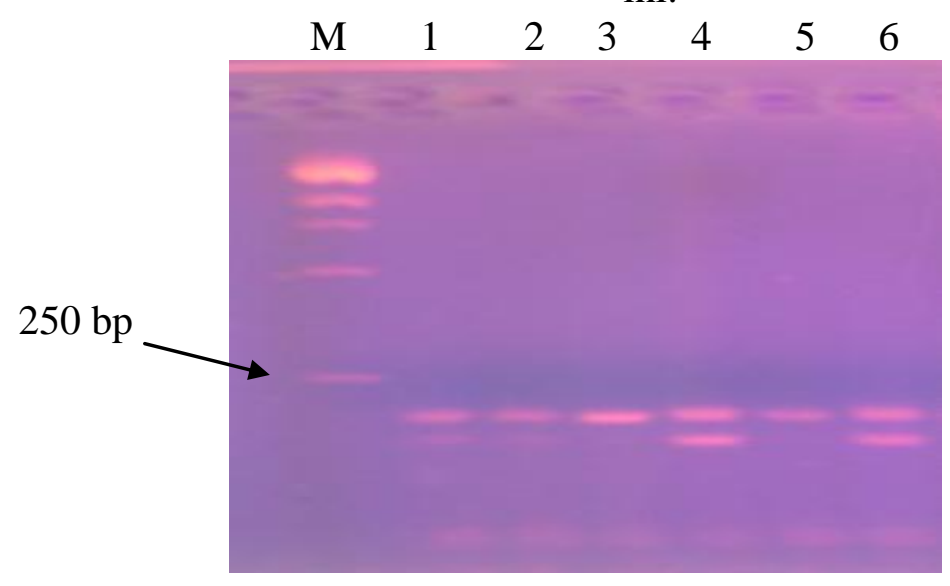

Gambar 1 Hasil Amplifikasi PCR dengan Primer 4a4b

( $\mathrm{M}=$ marker $1 \mathrm{~kb}$ Leader, no $1-6$ adalah no sampel)

Gambar 1 adalah menunjukkan hasil amplifikasi DNA dengan menggunakan primer intron 4a4b. Dari 6 sampel dapat kita simpulkan bahwa sebahagian kecil sampel memiliki alel intron 4b (sampel nomor 3 dan 5) karena hanya menunjukkan satu pita saja yaitu pada 210 bp dan yang lainnya adalah intron $4 \mathrm{a} 4 \mathrm{~b}$ dengan dua pita yaitu ukuran 210 bp dan 183 bp.

Tabel 4. Hubungan Polimorfisme Gen eNOS3 Alel Intron 4a4b dengan Kejadian Hipertensi pada Subjek Penelitian

\begin{tabular}{|c|c|c|c|c|c|}
\hline \multirow{3}{*}{ Alel } & \multicolumn{4}{|c|}{ Kelompok } & \multirow{3}{*}{$\underset{\text { Value }}{\mathbf{p}}$} \\
\hline & \multicolumn{2}{|c|}{ Kasus } & \multicolumn{2}{|c|}{ Kontrol } & \\
\hline & f & $\%$ & f & $\%$ & \\
\hline - Intron 4a & 1 & 50 & 1 & 50 & \\
\hline - Intron 4b & 55 & 55.5 & 44 & 44.5 & 0.06 \\
\hline
\end{tabular}


Setelah dilakukan amplifikasi terhadap seluruh subjek penelitian, maka didapatkan hasil seperti terlihat pada tabel 6. Pada kelompok kasus, sebagian besar subjek penelitian memiliki alel $4 \mathrm{~b}$. Tidak terdapat hubungan antara intron 4a4b dengan kejadian hipertensi.

\section{Tabel 5. Hubungan Alel Intron 4a4b dengan Kadar NO Plasma}

\begin{tabular}{|c|c|c|c|c|c|}
\hline \multirow{3}{*}{ Alel } & \multicolumn{4}{|c|}{ Kadar NO plasma $(\mu \mathrm{M} / \mathrm{L})$} & \multirow{3}{*}{$\begin{array}{c}p \\
\text { Value }\end{array}$} \\
\hline & \multicolumn{2}{|c|}{ Rendah } & \multicolumn{2}{|c|}{ Tinggi } & \\
\hline & f & $\%$ & f & $\%$ & \\
\hline Intron $4 a$ & 1 & 50 & 1 & 50 & \\
\hline Intron 4b & 66 & 66.7 & 33 & 33.3 & 0.88 \\
\hline Intron $4 a 4 b$ & 19 & 65.5 & 10 & 34.5 & \\
\hline
\end{tabular}

Pada tabel 5 dapat dilihat bahwa kadar NO plasma yang rendah lebih banyak ditemukan pada intron $4 \mathrm{~b}$. Tidak terdapat hubungan antara alel intron $4 \mathrm{a} 4 \mathrm{~b}$ dengan kadar NO plasma ( $\mathrm{p}>0.05)$.

Tabel 6. Hubungan Asupan Mikronutrien dengan Kadar NO Plasma Berdasarkan Alel Intron 4a4b pada Kelompok Kasus

\begin{tabular}{|c|c|c|c|c|c|c|c|c|c|}
\hline \multirow[t]{3}{*}{ Zat Gizi } & & \multirow[b]{3}{*}{ Kategori } & \multicolumn{4}{|c|}{ Kadar NO Plasma $(\mu \mathrm{M} / \mathrm{L})$} & \multicolumn{2}{|c|}{ Total } & \multirow{3}{*}{$\begin{array}{c}\mathbf{p} \\
\text { value }\end{array}$} \\
\hline & & & \multicolumn{2}{|c|}{ Rendah } & \multicolumn{2}{|c|}{ Tinggi } & \multirow[b]{2}{*}{$\mathbf{f}$} & \multirow[b]{2}{*}{$\%$} & \\
\hline & Alel & & f & $\%$ & $f$ & $\%$ & & & \\
\hline \multirow{6}{*}{ Vit C } & \multirow[t]{2}{*}{$4 a$} & Kurang & 0 & 0 & 0 & 0 & 0 & 0 & \\
\hline & & Cukup & 1 & 100 & 0 & 0 & 1 & 100 & \\
\hline & \multirow[t]{2}{*}{$4 \mathrm{~b}$} & Kurang & 4 & 57.1 & 3 & 42.0 & 7 & 100 & \\
\hline & & Cukup & 34 & 70.8 & 14 & 29.2 & 48 & 100 & 0.13 \\
\hline & \multirow[t]{2}{*}{$4 a 4 b$} & Kurang & 0 & 0 & 0 & 0 & 0 & 0 & \\
\hline & & Cukup & 7 & 77.8 & 2 & 22.2 & 9 & 100 & \\
\hline \multirow{6}{*}{ Vit E } & \multirow[t]{2}{*}{$4 a$} & Kurang & 0 & 0 & 0 & 0 & 0 & 100 & \\
\hline & & Cukup & 1 & 100 & 0 & 0 & 1 & 100 & \\
\hline & \multirow[t]{2}{*}{$4 b$} & Kurang & 26 & 76.5 & 8 & 23.5 & 34 & 100 & \\
\hline & & Cukup & 12 & 57.1 & 9 & 42.9 & 21 & 100 & 0.52 \\
\hline & \multirow[t]{2}{*}{$4 a 4 b$} & Kurang & 7 & 100 & 0 & 0 & 7 & 100 & \\
\hline & & Cukup & 0 & 0 & 2 & 100 & 2 & 100 & 0.50 \\
\hline \multirow{6}{*}{ Retinol } & \multirow[t]{2}{*}{$4 a$} & Kurang & 0 & 0 & 0 & 0 & 0 & 0 & \\
\hline & & Cukup & 1 & 100 & 0 & 0 & 1 & 100 & \\
\hline & \multirow[t]{2}{*}{$4 b$} & Kurang & 21 & 61.8 & 13 & 38.2 & 34 & 100 & \\
\hline & & Cukup & 17 & 81 & 4 & 19 & 21 & 100 & 0.14 \\
\hline & \multirow[t]{2}{*}{$4 a 4 b$} & Kurang & 4 & 80 & 1 & 20 & 5 & 100 & \\
\hline & & Cukup & 3 & 75 & 1 & 25 & 4 & 100 & 1.00 \\
\hline \multirow{6}{*}{ Karotenoid } & \multirow[t]{2}{*}{$4 a$} & Kurang & 0 & 0 & 0 & 0 & 0 & 0 & \\
\hline & & Cukup & 1 & 100 & 0 & 0 & 1 & 100 & \\
\hline & \multirow[t]{2}{*}{$4 b$} & Kurang & 25 & 75.8 & 8 & 24.2 & 33 & 100 & \\
\hline & & Cukup & 13 & 59.1 & 9 & 40.9 & 22 & 100 & 0.19 \\
\hline & \multirow[t]{2}{*}{$4 a 4 b$} & Kurang & 4 & 100 & 0 & 0 & 4 & 100 & \\
\hline & & Cukup & 3 & 60 & 2 & 40 & 5 & 100 & 0.44 \\
\hline \multirow{6}{*}{ Flavonoid } & \multirow[t]{2}{*}{$4 a$} & Kurang & 0 & 0 & 0 & 0 & 0 & 0 & \\
\hline & & Cukup & 1 & 100 & 0 & 0 & 1 & 100 & \\
\hline & $4 b$ & Kurang & 23 & 74.2 & 8 & 8 & 25.8 & 100 & \\
\hline & & Cukup & 15 & 62.5 & 9 & 37.5 & 24 & 100 & 0.41 \\
\hline & $4 a 4 b$ & Kurang & 4 & 66.7 & 2 & 33.3 & 6 & 100 & \\
\hline & & Cukup & 3 & 100 & 0 & 0 & 3 & 100 & 0.05 \\
\hline
\end{tabular}


$\begin{array}{lll}\text { Tabel } & 6 \text { menggambarkan hubungan } \\ \text { asupan mikronutrien dengan kadar NO }\end{array}$ plasma pada kelompok hipertensi dengan alel intron 4a4b. Pada alel intron $4 \mathrm{~b}$, kadar NO plasma yang tinggi lebih banyak ditemukan pada asupan vitamin $\mathrm{C}$ dan retinol kurang tetapi dengan asupan vitamin $\mathrm{E}$, karotenoid dan flavonoid cukup, sedangkan pada intron $4 \mathrm{a} 4 \mathrm{~b}$, kadar NO plasma yang tinggi lebih banyak ditemukan pada asupan vitamin $\mathrm{C}$, vitamin $\mathrm{E}$, retinol dan karotenoid cukup tetapi asupan flavonoid kurang. Tidak terdapat hubungan bermakna antara asupan mikronutrien dengan kadar NO plasma pada kelompok kasus dengan alel intron $4 \mathrm{a} 4 \mathrm{~b}(\mathrm{p}>0.05)$.

\section{Diskusi \\ Kadar NO Plasma}

Pada penelitian ini didapatkan rerata kadar NO plasma pada kelompok hipertensi adalah $26.91 \pm 15.40 \mu \mathrm{Mol} / \mathrm{L}$ dan kelompok normotensi $25.79 \pm 15.04$ $\mu \mathrm{Mol} / \mathrm{L}$. Hasil ini sesuai dengan kadar NO plasma normal yaitu $25-45$ $\mu \mathrm{mol} / \mathrm{L}$ tetapi berada pada kadar normal paling rendah. Tidak terdapat berbedaan bermakna kadar NO plasma antara kelompok hipertensi dengan normotensi ( $>>0.05)$.

Penelitian yang sama telah dilaporkan oleh Moriel et al ( 2002), penelitian dilakukan pada 11 penderita hipertensi berusia $57.8 \pm 9.7$ tahun dan 11 pasien normotensi berusia $48.4 \pm 7$ tahun. Hasil penelitian ini menyatakan bahwa tidak terdapat perbedaan bermakna kadar NO plasma antara penderita hipertensi dengan normotensi dengan kadar NO penderita hipertensi adalah $18.3 \pm 10.7 \mu \mathrm{mol} / \mathrm{L}$ dan penderita normotensi $20.7 \pm 16 \mu \mathrm{mol} / \mathrm{L}$. ${ }^{(16)}$

Hasil penelitian ini berbeda dengan penelitian yang dilakukan oleh Kitanovska et al, 2005. Penelitian dilakukan pada 26 wanita hipertensi berusia $37.6 \pm 4.6$ tahun dan 11 wanita normotensi berusia $35 \pm 6.7$ tahun. Hasil penelitian ini adalah kadar NO plasma pada wanita hipertensi secara bermakna lebih rendah dibandingkan wanita normotensi dengan nilai median NO adalah $22(11-35 \mu \mathrm{M} / \mathrm{L})$ pada hipertensi dan $37.5(11-66 \mu \mathrm{M} / \mathrm{L})$ pada wanita normotensi. Perbedaan hasil penelitian ini disebabkan karena adanya perbedaan karakteristik sampel penelitian. Kitanovska et al melakukan penelitian pada wanita premenopause yang berusia dibawah 40 tahun sedangkan pada penelitian ini dilakukan pada subjek lakilaki dan perempuan dan lebih dari separoh subjek penelitian baik pada kelompok kasus maupun kontrol sudah berusia di atas 40 tahun. Usia dapat mempengaruhi kemampuan endotel untuk mensintesis NO. Pada usia lanjut kemampuan endotel pembuluh darah untuk menghasilkan NO sudah mulai berkurang. Pada kedua kelompok penelitian, umumnya subjek wanita sudah menopause $(96.1 \%$ dan $84.3 \%$. Hormon estrogen merupakan salah satu faktor yang dapat mempengaruhi kadar NO plasma. ${ }^{(17)}$

\section{Polimorfisme gen eNOS3 Alel Intron 4a4b}

Gen eNOS3 merupakan salah satu gen yang diduga berhubungan dengan kejadian hipertensi. Sampai saat ini sudah teridentifikasi tiga polimorfisme gen eNOS3 yang berhubungan dengan kejadian hipertensi esensial yaitu Glu298Asp, -786T $>C$ dan intron 4a4b. Pada penelitian ini Alel intron 4a4b ditemukan hanya $1.5 \%$ pada kelompok kasus dan kelompok kontrol. Tidak terdapat hubungan yang bermakna antara alel 4a4b dengan kejadian hipertensi pada subjek penelitian.

Hasil penelitian ini sesuai dengan penelitian yang dilakukan oleh Kato et al (2004). Penelitian dilakukan terhadap masyarakat Jepang yang terdiri dari 549 pasien hipertensi dan 513 normotensi. Alel Glu298Asp ditemukan sebanyak $8.4 \%$ pada kelompok hipertensi dan $8.2 \%$ pada kelompok normotensi. Tidak terdapat hubungan yang bermakna antara kejadian hipertensi dengan gen eNOS3 
alel Glu298Asp dan intron 4a4b. ${ }^{(18)}$ Penelitian Miyamoto et al (1998), pada masyarakat Jepang, alel Glu298Asp berhubungan dengan kejadian hipertensi dan hal yang sama juga dilaporkan oleh Lacolley et al (1998) pada masyarakat Caucasian bukan alel intron $4 \mathrm{a} 4 \mathrm{~b} .^{(9.19)}$

Penelitian yang sama juga dilaporkan oleh Colombo et al (2003) pada populasi Italia. Penelitian ini bertujuan untuk melihat hubungan gen eNOS3 dengan kejadian cardio varcular diseases (CAD) pada terhadap 268 kasus dan 147 kontrol. Hasilnya adalah gen eNOS3 alel Glu298Asp dan -786T $>$ C berhubungan bermakna dengan kejadian CVD dan intron 4a4b tidak ada hubungan dengan kejadian CAD. ${ }^{(13)}$

Penelitian Qi et al (2006) melaporkan bahwa polimorfisme gen eNOS3 yang berhubungan dengan kejadian hipertensi adalah -786TG $>\mathrm{C}$ dan intron 4a4b tetapi glu298Asp tidak berhubungan dengan kejadian hipertensi pada masyarakat Cina. Penelitian Li et al (2004) juga melaporkan bahwa alel T786C berhubungan dengan kejadian hipertensi pada masyarakat Afrika Selatan. ${ }^{(20.21)}$

Perbedaan hasil penelitian ini disebabkan bahwa adanya perbedaan etnik, masing-masing etnik mempunyai polimorfisme yang spesifik yang berhubungan dengan kejadian hipertensi. Selain perbedaan etnik, keadaan demografis dan geografis suatu daerah diduga sebagai faktor yang menyebabkan perbedaan hasil penelitian tersebut. ${ }^{(17)}$

\section{Hubungan asupan mikronutrien dengan kadar NO plasma}

Vitamin $\mathrm{C}$ dan vitamin $\mathrm{E}$ merupakan salah satu mikronutrien yang dapat mempengaruhi kadar NO plasma. Vitamin $\mathrm{C}$ adalah vitamin larut air dengan angka kecukupan gizi yang dianjurkan adalah $60 \mathrm{mg} / \mathrm{hari}$. Pada penelitian ini didapatkan rerata asupan vitamin $\mathrm{C}$ pada kelompok kasus dan kontrol adalah $150.06 \pm 85.45 \mathrm{mg} / \mathrm{hr}$ dan $140.97 \pm 85.25 \mathrm{mg} / \mathrm{hr}$. Hasil penelitian ini lebih tinggi dari penelitian Purwantyastuti (2000) melaporkan rerata asupan vitamin $\mathrm{C}$ pada etnik minangkabau adalah $115 \pm 13 \mathrm{mg}$, Hatma (2001) menemukan median asupan vitamin $\mathrm{C}$ pada etnik Minagkabau adalah $48.4 \mathrm{mg}$, dan Delmi (2003) menemukan median asupan vitamin $\mathrm{C}$ adalah 35 mg. ${ }^{(22-24)}$

Rerata asupan vitamin $\mathrm{E}$ adalah $14.65 \pm 8.13 \mathrm{mg}$ pada kelompok kasus dan $15.38 \pm 11.11 \mathrm{mg}$ pada kelompok kontrol. Hasil ini lebih tinggi dari penelitian Purwantyastuti (2000), Hatma (2001) dan Delmi (2003) dengan nilai masing-masing $3.6 \pm 0.4 \mathrm{mg}, 3.1 \mathrm{mg}$ dan $0.5 \mathrm{mg}$. ${ }^{(22-24)}$

Pada penelitian ini tidak terdapat perbedaan bermakna rata-rata asupan vitamin $\mathrm{C}$ dan vitamin $\mathrm{E}$ pada kedua kelompok penelitian dan tidak terdapat hubungan antara asupan vitamin $\mathrm{C}$ dengan kadar NO plasma baik pada kelompok kasus maupun kelompok kontrol. Hasil ini berbeda dengan hasil penelitian Livius et al pada tahun 2003. ${ }^{(14)}$ Penelitian invivo ini dilakukan pada hewan coba yang dibagi menjadi dua kelompok. Kelompok satu adalah tikus normal sedang kelompok lainnya tikus dengan defisiensi apo E. Masingmasing kelompok diberi diet tinggi lemak dengan vitamin $\mathrm{C}$ atau vitamin $\mathrm{E}$, selama 26-28 minggu. Hasil penelitian ini menunjukkan bahwa suplementasi vitamin $\mathrm{C}$ jangka panjang secara bermakna meningkatkan aktivitas eNOS dan tidak mempengaruhi eNOS pada tikus normal tetapi tidak pada tikus defisiensi Apo-E. Efek vitamin C terhadap aktivitas eNOS adalah melalui kemampuan vitamin $\mathrm{C}$ dalam menstabilisasi BH4. 7.8-dihydrobiopterin menurun dan fungsi endotel vaskuler membaik. Efek tersebut tidak ditemukan pada pemberian vitamin E jangka panjang. 
Efek vitamin $\mathrm{C}$ dan vitamin $\mathrm{E}$ seperti tinggi lemak dan rendah sayur terhadap kadar NO plasma juga serta buah-buahan sebagai sumber dilaporkan oleh Ulker et al (2003). antioksidan (Bolton-Smith et al, 1991). Penelitian dilakukan pada tikus jantan Penelitian pada penderita penyakit berusia $20-22$ minggu yang menderita jantung koroner melaporkan bahwa hipertensi (Wistar Hypertensive Rats/ asupan tinggi lemak total dan rendah WHR) dan normotensi (Wistar Kyoto sayur dan buah lebih banyak ditemukan Rats/ WKY). Dari penelitian ini pada subjek penelitian dengan tingkat didapatkan hasil bahwa pemberian pendidikan rendah (Erkkila et al, 1999). $\mathrm{NAD}(\mathrm{P}) \mathrm{H}$ oksidase inhibitor secara Buah dan sayur kurang memberi rasa bermakna dapat menurunkan produksi kenyang dan harganya lebih mahal radikal superoksida. Inkubasi SHR dan terutama buah-buahan. Hal ini WKY dengan vitamin $\mathrm{C}$ dan vitamin $\mathrm{E}$ menyebabkan individu dengan tingkat dosis tinggi dapat memperbaiki fungsi pendidikan dan sosioekonomi rendah endotel, menurunkan produksi cenderung memilih makanan sebagai superoksida sama baiknya dengan sumber energi dan dapat memberi rasa pemberian $\mathrm{NAD}(\mathrm{P}) \mathrm{H}$, meningkatkan kenyang daripada memilih makanan aktivitas eNOS dan regenerasi NO. Efek sehat. ${ }^{(24)}$

vitamin C' dan vitamin E karena kemampuan kedua vitamin tersebut sebagai antioksidan dan meregulasi superoksida dismutase (SOD). ${ }^{(15)}$

Efek kedua vitamin lebih tinggi secara bermakna pada WKY. Kemampuan vitamin $\mathrm{C}$ dan $\mathrm{E}$ memodulasi $\mathrm{NAD}(\mathrm{P}) \mathrm{H}$ dan aktivitas eNOS sampai saat ini belum diketahui secara pasti tetapi diduga vitamin terlibat dalam proses transkripsi dan posttranslasi dari $\mathrm{NAD}(\mathrm{P}) \mathrm{H}$ oksidase dan eNOS.Vitamin E merupakan antioksidan lipofilik, dapat memodulasi interaksi antara citokrom b558, bagian membran yang berikatan dengan enzim $\mathrm{NAD}(\mathrm{P}) \mathrm{H}$ oksidase yang dapat mengaktivasi dan stabilisasi enzim. Vitamin E akan diambil oleh LDL sehingga memperbaiki fungsi endotel dengan cara menurunkan sensitivitas LDL terhadap proses oksidasi, dan reaksi ini menjadi lebih kuat bila terdapat antioksidan lain seperti vitamin C. ${ }^{(15)}$

Perbedaan hasil ini kemungkinan disebabkan oleh perbedaan umur, pendidikan, sosioekonomi dan lingkungan dari subjek penelitian. Pola makan dapat dipengaruhi oleh beberapa faktor seperti pendidikan, sosioekonomi, kultur, kebiasaan dan lingkungan. Individu dengan sosioekonomi rendah cenderung memilih makanan tidak sehat

Retinol dan karotenoid adalah antioksidan lipofilik. Pada penelitian ini didapatkan rerata asupan retinol pada kelompok kasus dan kontrol adalah $437.98 \pm 242.83 \mathrm{mg} / \mathrm{hr}$ dan $536.80 \pm$ $914.97 \mathrm{mg} / \mathrm{hr}$ sedangkan rerata asupan karotenoid pada kedua kelompok adalah $6123.25 \pm 4285.72 \mathrm{mg} / \mathrm{hr}$ dan $3893.63 \pm$ $2697.16 \mathrm{mg} / \mathrm{hr}$. Terdapat perbedaan bermakna asupan karotenoid antara kelompok kasus dengan kelompok kontrol. Pada kelompok kontrol terdapat hubungan yang bermakna antara asupan retinol dengan kadar NO plasma pada alel intron 4b.

All-trans retinoic acid (atRA) memiliki peranan yang penting dalam perkembangan dan maturitas sistem kardiovaskular. Pengaruh atRA terhadap kadar NO plasma sudah diteliti oleh Achan et al,(2002). Penelitian dilakukan pada sel endotel Murine yang telah diinkubasi dengan atau tanpa atRA. Hasilnya menunjukkan bahwa atRA secara bermakna dapat meningkatkan sintesis NO dan DDAH II.Peningkatan kadar NO plasma difasilitasi oleh DDHA II. $^{(25)}$

Pada penelitian ini rerata asupan flavonoid adalah`117.14 $\pm 60.23 \mathrm{mg} / \mathrm{hr}$ pada kelompok kasus dan $101.51 \pm 46.08$ $\mathrm{mg} / \mathrm{hr}$ pada kelompok kontrol.Flavonoid merupakan derivat polifenol dari 
diphenylpyrans, merupakan senyawa yang hanya ditemukan pada tumbuhtumbuhan. Senyawa ini mempunyai efek ateroprotektif yang meliputi efek antioksidan yang sangat kuat , meningkatkan kemampuan trombosit untuk melepaskan NO dan menghambat pembentukan trombus. Pemberian jus anggur selama 14 hari terhadap laki-laki sehat menyebabkan penurunan agregasi trombosit, sintesis NO meningkat dan produksi radikal superoksid menurun. ${ }^{(26)}$

\section{Kesimpulan}

1. Polimorfisme gen eNOS3 alel intron $4 \mathrm{a} 4 \mathrm{~b}$ tidak berhubungan dengan kejadian hipertensi pada etnik inangkabau. Sebagian besar gen eNOS3 alel intron 4 pada kelompok ipertensi adalah intron $4 \mathrm{~b}$ dan kelompok normotensi alel intron $4 \mathrm{a} 4 \mathrm{~b}$.

2. Kadar NO plasma pada penderita hipertensi dan normotensi adalah normal tetap berada pada kadar normal paling rendah. Tidak terdapat perbedaan kadar NO antara penderita hipertensi dan normotensi etnik Minangkabau.

3. Asupan Mikronutrien tidak berhubungan dengan kadar NO plasma pada subjek hipertensi dengan gen eNOS3 alel intron $4 \mathrm{a} 4 \mathrm{~b}$

\section{KEPUSTAKAAN}

1. Chehab IA, 1993. Survey Hipertensi di Desa Tani Kutosari Sumatera Selatan. Medika 1: 26 -35 .

2. Armilawaty, Amalia $\mathrm{H}$ dan Amiruddin, 2007. Hipertensi dan faktor risikonya dalam Kajian epidemiologi.Bagian Epidemiologi. FKM UNHAS.
3. Woodwell DA, 2000. Advance data from vital and health statistics, in National ambulatory Medical Survey. National Center for Health Statistics Hypertension $44: 419$.

4. Hadi H, 2005. Beban Ganda Masalah Gizi dan Implikasinya Terhadap Kebijakan Pembangunan Kesehatan Nasional. Pidato Pengukuhan Jabatan Guru Besar pada Fakultas Kedokteran UGM Yogyakarta.

5. Dinas Kesehatan Provinsi Sumatera Barat. Profil Kesehatan Provinsi Sumatera Barat. 2007.

6. Darmojo B, 2001. Mengamati Perjalanan Epidemiologi Hipertensi di Indonesia. Medika 7 : 442-448.

7. Sargowo D, 2008. New Perspective in Hipertension Research; Potentials of Vascular Molecular Biology. Disampaikan pada pelatihan Nutrigenomik, Analisis Genetika Molekuler dan Nutrien Sebagai Faktor Risiko Hipertensi, Yogyakarta.

8. Casas JP, Cavalleri GL, Bautista LE, et al, 2006.Endothelial Nitric Oxide Synthase Gene Polymorphisms and Cardiocascular Disease. A Huge Review.

9. Miyamoto Y, Saito Y, kajiyama $\mathrm{N}$, et al, 1998. Endhothelial Nitric Oxide Synthase Gene is Positively Associated With Essential Hypertension. Hypertension $32: 3-8$. 
10. Kim IJ, Bae J, Lim S.W et al, 2006. Influence of endothelial nitric oxide synthase gene polymorphisms $\quad(-786>C, 4 a 4 b$, $894 \mathrm{G}>\mathrm{T})$ in Korean patiens with coronary artery disease. Thrombo Res 119 (15) : $579-85$.

11. Bonnardeaux A., Sophie N, Anne C et al, 1995. Lack of Evidence for Linkage of The Endothelial Cell Nitric Oxide Synthase Gene to Essential Hypertension. Circulation 91: 96-102.

12. Rankinen T, Rice T, Perusse L, et al, 2000. NOS3 Glu298Asp Genotype and Blood Pressure Response to Endurance Training. Hypertension 32: 885-97.

13. Colombo MG, Paradossi U, Andreassi MG et al, 2003. Endhotelial Nitric Oxide Synthase Gene Polymorphisms and Risk of Coronary Artery Disease. Clinical chemistry 49 (3) : 389-95.

14. Ulker S, McKeown PP dan Bayraktutan U, 2003.Vitamins Reverse Endothelial Dysfunction Through Regulation of eNOS and NAD (P) H Oxidase Activities. Hypertension 41: 534.

15. Livius VD, Sheldon M, Darcy R, at al. 2003. Long Term Vitamin C Treatment Increases Vascular Tetrahydrobiopterin Levels and Nitric Oxide Synthase Activity. Circulation Research 192 : 88.

16. Moriel P, Sevanian A, Ajzen S, Zanella MT, Plavnik FL, Rubbo $\mathrm{H}$ et al, 2002. Nitric oxide, cholesterol oxides and endothelium - dependent vasodilation in plasma of patients with essential hypertension. Braz J Med Biol Res 35 (11) : 1301 1309.
17. Kitanovska BG, Zahrovska K, Bogdanovska S, Lozance L, Andreevska GS, 2005. Decreased nitric oxide in women with essential hypertension in pre hypertension phase. Croat Med J $46(6): 889-895$.

18. Kato N, Sugiyama T, Morita H, Nabika T, Kurihara H, Yamori Y, et al. Lack of Evidence for Association Between the Endothelial Nitric Oxide Synthase Gene and Hypertension. Hypertension 1999;33:933-36

19. Lacolley P, Gautier S, Poirier O, Pannier B, Cambien $F$ and Benetos A. Nitric Oxide Synthase Gene Polimorfism, Blood Pressure and Aortic Stiffness in Normotensive and Hypertensive Subjects. J Hypertensi. 1998 ; 16 : $31-35$.

20. Qi Z, Shao-yong S, Shu-feng C, Biao L, Dong-feng G. Association study of the endothelial nitric oxide synthase gene polymorphisms with essensial hypertension in northern Han Chinese. Chinese Medical Journal 2006; 13: 1065-71.

21. Li R., Lyn D, Lapu-Bula R, Oduwole A, Igho-Pemu $\mathrm{P}$, Lankford B, et al . Relation of endothelial nitric oxide synthase gene to plasma nitric oxide level, endothelial function, and blood pressure in African American. Am J Hypertens 2004; 17:56067.

22. Hatma RD, 2002 Nutrien intake and their relation to lipid profile in diverse ethnic population, Disertation. Post Graduate Program, University of Indonesia, Jakarta. 
23. Purwantyastuti, 2000. Relation of lipid peroxides to food habit, selected coronary heart disease risk factors and vitamin $\mathrm{E}$ supplementation in the elderly. Dissertation. Post Graduate Program University SeameoTropmed of Indonesia.

24. Delmi S, Rahayu S dan Astuty P, 2004. Pengaruh pola makan terhadap profil lipid dan MDA plasma laki-laki etnik Minangkabau, dalam Majalah Kedokteran Indonesia $32: 1-5$.
25. Achan V, Tran C.T.L, Arr goni F.A, et al, 2002.. all-transRetinoic Acid Increases Nitric Oxide Synthesis by Endothelial Cells. Circulation Research 90 : 764.

26. Freedman JE, Parker C, Li L et al, 2001. Select Flavonoids and Whole Juice From Purple Grapes Inhibit Platelet Fuction and Enhanced Nitric Oxide Release. Circulation 103 : 2792. 